\title{
Idiosyncratic Risk and the Cross-Section of European Insurance Equity Returns
}

\author{
Hassen Raîs
}

\begin{abstract}
Based on a survey of 203 Insurance equities from European capital markets over the 2001-2014 period, this article analyses the role of idiosyncratic risk in the pricing of European insurance equities. The capital asset pricing model predicts that in equilibrium, investors should hold the market portfolio. As a result, investors should only be rewarded for carrying undiversifiable systematic risk and not for diversifiable idiosyncratic risk. The framework of Fama and MacBeth is employed. Regressions of the cross-section of expected equity excess returns on idiosyncratic risk and other firm characteristics such as beta, size, book-to-market equity (BE/ME), momentum, liquidity and co-skewness are performed.

The empirical models reveal that the largest part of total volatility is idiosyncratic and therefore firm specific in nature. Simple cross-correlations indicate that high beta, small size, high BE/ME, low momentum, low liquidity and high co-skewness equities have higher idiosyncratic risk.
\end{abstract}

Index Terms - Insurance equities, cross-section, idiosyncratic risk, idiosyncratic volatility, EGARCH.

\section{INTRODUCTION}

Recent researches have questioned existing theories about the theoretical relationship between expected returns and risk. The capital asset pricing model (CAPM) predicts that in equilibrium investors should hold the market portfolio in which idiosyncratic risk is perfectly diversified and should not matter in asset pricing. However, recent empirical evidence contradicts this prediction because of several external factors, which impede investors from holding sufficiently diversified portfolios such as transaction costs, taxes, wealth constraints, liquidity, restriction on short sales, investment objectives and incomplete information. Variants of the standard asset-pricing model alleviate the assumption of perfect diversification and postulate a positive relationship between idiosyncratic risk and the cross-section of expected returns. Such, models developed by Merton [1], Goetzmann and et al. [2] and Malkiel and Xu [3] demonstrates that idiosyncratic risk can be priced in equilibrium if some investors are under-diversified and do not hold the market portfolio. Merton's basic intuition is that information about securities is costly to acquire. Therefore, it is neither optimal nor even plausible for investors to track every security in the market. These investors only follow a subset of the securities available in the market and construct their investment portfolios from these known securities. Since investors hold under-diversified portfolios, they demand compensation for securities' idiosyncratic volatility. However, the empirical

Manuscript received July 19, 2016; revised December 14, 2016.

The author is with Universite de Toulouse, France (e-mail: hassen.rais@live.fr). relationship between idiosyncratic risk and equities returns is conflicting and confusing. Scholars find Evidences. Such, Malkiel and $\mathrm{Xu}$ [3] reported that only firm-specific risk exhibited a significant upward trend during the 1962-1997 period, while market and industry volatilities showed no significant trend.

This article examines the role of idiosyncratic risk in the pricing of insurance equities. A separate examination of the relationship between idiosyncratic risk and the cross-section of European insurance equity returns is warranted for the reasons that, the nature of the insurance markets results in varied assets and equities being less exposed to idiosyncratic risk than other assets. Second, over longer time horizons insurance equities tend to perform over the market. This is likely to impact on both the level and pricing of idiosyncratic risk.

This research analyses a broad set of 203 insurances equities from 12 European capital markets over the 2001-2014 period. The framework of Fama and MacBeth [4] is employed to identify the potential relationship between idiosyncratic risk and individual European insurance equity returns. The pricing is also investigated using conditional framework with two variables used to proxy for expected idiosyncratic risk: realized idiosyncratic volatility and expected idiosyncratic volatility. Following studies such as Fu [5], Brandt and et al. [6], and Huang et al. [7], the study utilizes the Fama and French [8] three-factor model as the return generating process to derive the idiosyncratic volatility measures. Realized idiosyncratic volatility is measured as the standard deviation of the regression residuals while expected idiosyncratic volatility is derived as the forecasted residual volatility from a set of exponential generalized autoregressive conditional heteroskedasticity (EGARCH) models.

The cross-sectional regressions reveal that both measures of idiosyncratic risk are not priced unconditionally, supporting the conception of the CAPM that idiosyncratic risk is irrelevant in the pricing of risky assets. However, once conditioned on the general equity market or insurance equity market, a strong positive relationship between idiosyncratic risk and expected returns emerges in up-markets while the opposite relationship exists in down-markets. The relationship endures the inclusion of beta, size, book-to-market equity (BE/ME), momentum, liquidity and co-skewness. It is moreover robust to different time periods, return currency, return weighting, country effects and the measure of expected idiosyncratic volatility.

The article is organized as follows. Section II provides a detailed overview of related literature. Section III explains the methodical framework and the data selection process, while Section IV provides descriptive statistics and displays trends in realized idiosyncratic volatility. In Section V, 
results of the unconditional and conditional cross-section regressions are presented, and the robustness of the results is checked, while Section VI concludes.

\section{LITERATURE REVIEW}

The general finance literature has paid considerable attention to trends in and the pricing of idiosyncratic volatility. However, the results are not conclusive. A number of studies yield that idiosyncratic risk is positively related to stock returns. Eiling [9], yield that from 1962 to 1999, a positive relationship between monthly equal-weighted average idiosyncratic volatility and value-weighted portfolio returns existed. Using daily returns from 1962 to 2002 and the equal- and value-weighted volatility measure of Bali and et al. [10], Jiang and Lee [11] yield that positive shocks in lagged idiosyncratic volatility result in higher excess returns. Panousi and Papanikolaou [12] show that between 1975 and 2000 , the positive relationship to monthly stock returns is not only significant but also robust to the inclusion of other risk factors such as size, BE/ME and liquidity. Spiegel and Wang [13] examine the interaction between liquidity and idiosyncratic risk in the pricing of US equities from 1962 to 2003 and find that stock returns increase with idiosyncratic volatility and decrease with liquidity. Chua and et al. [14] show that after controlling for unexpected returns, a strong relationship between expected idiosyncratic volatility and expected returns exists from 1963 to 2003, which is robust to various firm characteristics as well as sample periods. Fu [5], [15] uses EGARCH models to forecast expected idiosyncratic volatilities and shows that monthly-expected returns are positively related to conditional idiosyncratic volatility from 1963 to 2006. Lastly, a recent paper by Garcia et al. [16] adds to the literature by showing that aggregate market returns are predictable by idiosyncratic variance from 1963 to 2006, which is however sensitive to the data frequency (monthly vs daily) and the return weighting equalvs value-weighted.

Yet, numerous studies question the documented positive relationship between idiosyncratic risk and expected returns. Bali and Cakici [17] show that the results of Chen and Petkova [18] are primarily driven by an underlying liquidity effect as well as small capitalization stocks and seem to depend on the weighting of portfolio returns as well as on the time period examined. Similar conclusions are drawn by Wei and Zhang [19], who highlight that their results are mainly driven by the 1990s. Bali and Cakici [17] highlight that from 1958 to 2004 the relationship between idiosyncratic volatility and the cross-section of stock returns largely depends on the data frequency used to calculate idiosyncratic volatility, the weighting scheme and breakpoints to calculate portfolio returns, as well as size, price and liquidity effects, as no unambiguous results concerning the sign and significance can be obtained. Boehme and et al.[20] show that when short-sale constraints are absent, idiosyncratic risk is positively related to the cross-section of returns, while the opposite holds in their presence. Guo et al. [21] question Fu [5] results by showing that the positive relationship is caused by an inherent look-ahead bias and after controlling for the bias is insignificant. Also Fink et al.[22] question the results of $\mathrm{Fu}[5]$ as they show that expected idiosyncratic volatility is not reliably priced in the cross-section of equity returns from 1963 to 2008, while unexpected idiosyncratic volatility is.

Several studies are moreover adding to the literature by showing that idiosyncratic volatility is negatively related to stock returns. Guo and Savickas [21] document a strong ability in forecasting excess stock market returns from 1962 to 2002 when both value-weighted idiosyncratic stock volatility and aggregate stock market volatility are used jointly, with idiosyncratic volatility being negatively related to excess returns. The study of Ang and et al. [23] shows that high idiosyncratic volatility results in low average returns from 1986 to 2000, which can neither be explained by aggregate volatility risk or a size, book-to-market, momentum or liquidity effect and does not depend on the time period under examination. The results are challenged by $\mathrm{Fu}$ [5], who attributes their findings to the return reversal of small stocks with high idiosyncratic volatilities in their sample.

Addressing the countering results, Huang and et al. [7] use different proxy and return frequencies for the calculation of idiosyncratic volatility along with different weighting schemes and time periods. The authors argue that the negative relationship documented in previous studies stems from an omitted variables bias induced by return reversals and the positive contemporaneous relationship between realized idiosyncratic volatility and stock returns, resulting in a negative bias. From 1963 to 2004, the study shows that the found negative relationship between stock returns and idiosyncratic volatility calculated from daily data turns insignificant once return reversals are accounted for. When using monthly data to forecast idiosyncratic risk, the relationship is positive and robust to return reversals.

While most research is conducted in the USA, there are now an increasing number of studies with respect to global capital markets. Drew and Veeraraghavan [24] and Drew and et al. [25] provide evidence that stocks which show high idiosyncratic volatility have higher returns than their counterparts in several Asian markets. Drew and Veeraraghavan [24] show that from 1991 to 2001, stocks from Germany and the UK with higher idiosyncratic risk yield higher returns than their counterparts. Guo and Savickas [26] show that idiosyncratic volatility has a predictive power for aggregate stock market returns in several international markets. In cross-sectional tests, a positive relationship between idiosyncratic volatility and returns is documented. In a subsequent study using ten European capital markets, Angelidis and Tessaromatis [27] contend that idiosyncratic volatility, equal- or value-weighted, is unable to forecast future stock market returns, yet it possesses some explanatory power to predict the size and value premium. The results are the strongest for Germany and the UK, where idiosyncratic volatility is negatively related to market returns. Brockman and al. [28] examine 44 international equity markets from 1980 to 2007 and show that idiosyncratic risk is positively related to expected returns in 36 countries, including 12 European countries. Contrary evidence is provided by Ang and et al. [29] who show that from 1980 to 2003, past high idiosyncratic volatility is negatively related to future stock returns in 23 developed markets. Lastly, Marcelo and al. [30] show that for equities listed on the Spanish stock market from 
1987 to 2007, a positive relationship exists between returns and individual security idiosyncratic volatility, while a negative relationship exists with an aggregate measure of idiosyncratic risk.

While studies on idiosyncratic risk in general stock returns are numerous, little attention has been paid to insurance equities in particular. Storesletten and et al.[31] analyze the relative importance of stock, bond and asset factors in explaining insurance firms returns and show that from 1978 to 1998 , idiosyncratic risk is the most important component of total volatility and increased steadily, which is not accounted for by the three utilized factors. Using a similar study design, Luo, X. Bhattacharya, C. [32], examine the dynamic behavior of insurance volatility using a GARCH model from 1972 to 2006 . A positive relationship between expected return and expected risk seems to preponderate the years pre-1993 but the relationship disappears after 1993. Unconditional volatility seems to have increased after 1993, while it is less persistent than during the pre-1993 period. Choi and et al. [33] extend the previous studies by examining the relevance of idiosyncratic risk in explaining the cross-section of US insurance returns. They document a positive relationship between idiosyncratic volatility and cross-sectional returns. Moreover, the authors show that the size and BE/ME effect cease to be significant once idiosyncratic volatility is included, while the momentum effect maintains its significance.

\section{Methodology AND DATA}

The following section describes the cross-sectional framework along with the different measures of idiosyncratic volatility, which are used to proxy for idiosyncratic risk.

\section{A. Framework}

The framework of Fama and MacBeth [4] is employed to identify the potential relationship between idiosyncratic risk and the returns of European insurance equities. Each month $t$ regressions of the cross-section of expected equity excess returns on expected idiosyncratic risk and other firm characteristics are performed:

$$
\begin{gathered}
R_{i, t} \quad r_{f_{t}}={ }_{0, t}+\sum_{k=1}^{K}{ }_{k, t} E_{t, 1}\left[X_{k, i, t}\right]+{ }_{t} E_{t, 1}\left[I V O L_{i, t}\right]+{ }_{i, t} \\
n=1,2, \ldots, N ; t=1,2, \ldots, T
\end{gathered}
$$

where $R_{i, t}$ is the discrete return on insurance equity $i$ and $r_{f t}$ is the risk-free rate in month $t . E_{t-1}[$.$] represents the conditional$ expectation based on the information set known at time $\mathrm{t}-1$. $X_{k, i, t}$ represents other explanatory variables of cross-sectional returns such as beta, size, $B E / M E$, momentum and a liquidity measure. $E_{t-1}\left[I \mathrm{Vol}_{i, t}\right]$ is the idiosyncratic volatility of equity $i$ in month $t . E_{i, t}$ are the regression residuals. $N_{t}$ is the number of insurance equities included in the regression in month $t$ and $T$ is the total number of time periods. The null hypothesis is that $\delta_{t}=0$, and accordingly that idiosyncratic volatility is not priced.

The risk premia and their significances are assessed by computing Fama and MacBeth [34] coefficients and standard errors. The coefficient estimate is the average of the $T$ estimates:

$$
\overline{\hat{\gamma}}_{k}=\frac{1}{T} \sum_{t=1}^{T} \hat{\gamma}_{k, t}
$$

The estimated variance of the Fama and MacBeth [34] estimate is calculated as:

$$
S^{2}\left(\overline{\hat{\gamma}}_{k}\right)=\frac{1}{T} \sum_{t=1}^{T} \frac{\left(\hat{\gamma}_{k, t}-\overline{\hat{\gamma}}_{k}\right)^{2}}{T-1}
$$

Finally, the t-statistic is calculated by dividing the Fama and MacBeth [34] coefficients by its time-series standard error.

$$
t\left(\overline{\hat{\gamma}}_{k}\right)=\frac{\overline{\hat{\gamma}}_{k}}{\sqrt{s^{2}\left(\overline{\hat{\gamma}}_{k}\right) / T}}
$$

The pricing is also investigated using the conditional framework of Pettengill as in Spiegel and et al. [13]. Each month $t$, the following regression is performed:

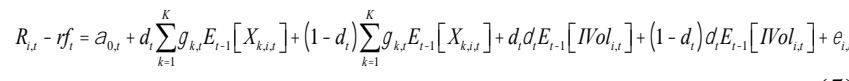

$$
\begin{aligned}
& n=1,2, \ldots, N ; t=1,2, \ldots, T
\end{aligned}
$$

where $d_{t}$ is a dummy variable which equals 1 if $\left(r_{m t}-r_{f t}\right)>0$ (i.e. when the excess market return is positive) and 0 if $\left(r_{m t}-\right.$ $\left.r_{f t}\right)<0$ (i.e. when the excess market return is negative). The excess market return is either measured as that of the general equity market or the insurance equity market, respectively. The coefficients and standard errors are calculated as described in equations (2) and (3).

\section{B. Estimation of Idiosyncratic Volatility}

Following studies such as Ang et al. [23], [29], Fu [15], Huang et al. [7], the study utilizes the Fama and French [19] three-factor model as the return generating process to derive the idiosyncratic volatility measures:

$$
\begin{gathered}
R_{i, t} \quad r f_{t}={ }_{i}+b_{i}\left(r m_{t} \quad r f_{t}\right)+s_{i} S M B_{t}+h_{i} H M L_{t}+{ }_{i, t} \\
t=1,2, \ldots, T \\
i, t \quad N\left(0, \quad \begin{array}{l}
2 \\
i, t
\end{array}\right)
\end{gathered}
$$

where $R_{i, t}$ is the discrete return on insurance equity $i, r_{f t}$ is the risk-free rate and $r_{m t}$ the return on the market portfolio in month $t . S M B_{t}$ (small minus big) is the return on the portfolio mimicking the size effect and HMLt (high minus low) is the return on the portfolio mimicking the value effect. $\varepsilon_{i, t}$ are the regression residuals, which are by construction independent of the utilized risk factors. $b_{i}, s_{i}$ and $h_{i}$ are the respective factor loadings. The Fama-French model uses equal-weighted returns denominated in Euro. Following studies such as Ang et al. [29], Fu [5], Huang et al. [29], realised idiosyncratic volatility is used as a proxy for idiosyncratic risk and measured as the standard deviation of the regression residuals.

Similar to Kearney and Poti [35] and Bekaert and et al. [36], the first measure of idiosyncratic volatility is derived by regressing weekly insurance equity excess returns on weekly Fama-French factors over a six-month window as described in equation (6). By using weekly instead of daily returns, the importance of asynchronous trading across the European countries is alleviated. The resulting realized idiosyncratic 
volatility is denoted in monthly frequency. The procedure is repeated for every semester in order to get semi-annual, non-overlapping estimates of idiosyncratic volatility. Similar to Kearney and Poti [35], two market-wide measures are constructed to analyze potential trends in realized idiosyncratic and total volatility. Both measures are derived as:

$$
\begin{gathered}
\text { IVol }={ }_{i=1}^{N} w_{i} \sqrt{\operatorname{Var}\left(i_{i, t}\right)} \\
\text { TVol }={ }_{i=1}^{N} w_{i} \sqrt{\operatorname{Var}\left(R_{i, t} \quad r f_{t}\right)}
\end{gathered}
$$

where $I V o l$ is the average idiosyncratic and TVol the average total volatility. Both are either equal- or value-weighted averages using the market capitalization at the end of the preceding semester to weight the individual volatilities. Following Chen and et al. [18] a variance decomposition approach is conducted to examine the proportion of idiosyncratic risk to the total risk of European insurance equities. To proxy how much of a insurance equity's total variance is due to firm-specific components, idiosyncratic variance is divided by the total variance:

$$
\text { ITVar }={ }_{i=1}^{N} w_{i} \frac{\operatorname{Var}\left({ }_{i, t}\right)}{\operatorname{Var}\left(R_{i, t} \quad r f_{t}\right)}
$$

The two weighting procedures are performed as before.

Only when realized idiosyncratic volatility is highly persistent following a random walk process can it is value in month $t-1$ be used as an estimate of the expected value in month $t, E_{t-1}\left[I V o l_{i, t}\right]$. As idiosyncratic risk is firm specific and accounts for such factors as infrequent earnings disclosures, property acquisitions and financings, and analyst ratings, it seems likely that realized idiosyncratic volatility is time-varying in nature. Supporting this conception, studies such as Fu [5] for US equities, Brockman et al. [28] for international equities, highlight that realized idiosyncratic volatility cannot be described as a random walk process, and accordingly should not be used to proxy future expected idiosyncratic volatility. To avoid the potential measurement errors, the study employs a set of EGARCH models to forecast expected idiosyncratic volatility. The return generating process follows the specification of the Fama and French [8] three-factor model, resulting in the following $\operatorname{EGARCH}(p, q)$ model specification:

$$
\begin{gathered}
R_{i, t} \quad r f_{t}={ }_{i}+b_{i}\left(r m_{t} \quad r f_{t}\right)+S_{i} S M B_{t}+h_{i} H M L_{t}+{ }_{i, t} \\
\text { i,t } \quad N\left(0, \begin{array}{l}
2 \\
i, t
\end{array}\right) \\
\ln \underset{i, t=}{2}={ }_{i}+\sum_{t=1}^{p} b_{i, l} \ln \underset{i, t 1}{2}+\sum_{k=1}^{q} c_{i, k}\left\{\left(\frac{i, t k}{i, t k}\right)+\left[\left|\begin{array}{c}
i, t k \\
i, t k
\end{array}\right|(2 /)^{1 / 2}\right]\right\}
\end{gathered}
$$

The expected idiosyncratic volatility is estimated as the square root of the conditional variance $\sigma^{2}{ }_{i, t}$, which is modeled as a function of the last $p$ residual variances and the last $q$ shocks.

The estimation of the expected idiosyncratic volatility uses an expanding rolling window over the previous months, requiring a minimum of 30 observations and using a maximum of 60 observations. For each insurance equity and month, monthly excess returns are regressed on monthly Fama-French factors as described in equation (10). The resulting residuals are subsequently used in the EGARCH models to forecast the expected idiosyncratic volatility in the next month, thereby providing an out-of-sample estimate, as in Guo and et al. [37]. Subsequently, the window is rolled one month forward and the procedure repeated.

\section{Data and Sample Selection}

The sample selection and screening procedure is similar to that of Spiegel and et al. [13] and Morelli and et al.[38]. The sample consists of all traded and defunct European insurance and general equities of the Thomson Reuters' research indices from 12 European countries, namely Austria, Belgium, Denmark, France, Germany, Ireland, Italy, The Netherlands, Norway, Spain, Sweden and the UK, and covers the time period from June 2001 to June 2014. The resulting initial sample consists of 28,852 equities. The sample is screened as proposed by Kearney and et al. [35] and Ince and et al. [39], to correct the documented issues with individual equity return data from Thomson Reuters Datastream. Moreover, all non-common equities are excluded. All remaining shares that are wrongly classified as common equity, such as closed-end funds, shares of beneficial interest, ADRs, warrants, etc. are dropped.

Total return indices, share prices, the market and book value of equity and turnover volume are extracted for each stock. Equities without full information are dropped from the sample. All variables are denominated in Euros. Total returns are calculated as monthly discrete returns. Following Fu [5], observations with monthly returns greater than 300 percent are deleted. The literature has identified firm size, the book-to-market value of equity ratio (BE/ME), momentum, liquidity and co-skewness to have an impact on the cross-section of stock returns besides beta. The beta of each equity is estimated each month from a market model as the coefficient on the excess market return, requiring at least 30 and using a maximum of 60 prior return observations. Firm size is calculated as a firm's market value of equity at the end of each month. BE/ME is calculated by dividing a firm's book value of equity at the end of the last year by its market value of equity at the end of June next year. Stocks with a negative $\mathrm{BE} / \mathrm{ME}$ are dropped from the analysis. As the book value of equity is available on an annual basis, the ratio is updated yearly. Momentum is calculated each month as the cumulative total return over the last 12 months, excluding the most recent observation. Turnover volume is the amount of shares traded in each month and is used to construct the liquidity measure of Drew and et al. [24] Turnover volume is multiplied by the average of the share price at the beginning and end of the month to proxy the Euro trading volume. The absolute stock return of the month is subsequently divided by the trading volume in million to derive the liquidity measure. A higher measure indicates a higher price reaction to trading activity, and therefore characterizes a more illiquid stock. Co-skewness is calculated each month following Choi and et al. [33] and defined as:

$$
C S K_{i, t}=\frac{E\left[\begin{array}{ll}
\lfloor, t & 2 \\
i, t
\end{array}\right\rfloor}{\sqrt{E\left[\begin{array}{c}
2 \\
i, t
\end{array}\right] E\left[\begin{array}{l}
2 \\
M, t
\end{array}\right]}}
$$

where $\varepsilon_{i, t}$ is the residual from regressing the excess return of equity $i$ on a constant and the contemporaneous excess market return and $\varepsilon_{M, t}$ is the difference of the market return 
from its mean value, $\varepsilon_{M, t}=r m_{t}-\overline{r m}$. Size, BE/ME, momentum, liquidity and co-skewness are winsorized by setting the 0.5 percent largest and smallest observations in each month equal to the next largest or smallest observation. Excluding equities without full information leads to a final sample of 10,008 general and 203 insurance equities.

\section{DESCRIPTIVE STATISTICS AND IDIOSYNCRATIC VOLATILITIES}

To derive $\mathrm{SMB}_{t}$ and $\mathrm{HML}_{t}$, the paper uses size and $\mathrm{BE} / \mathrm{ME}$ to sort all general equities at the end of June of each year, starting in June 2001. Following Chua and et al. [14] all general equities are ranked by size at the end of June each year. The median is used to split the sample into small and big stocks. Subsequently, the stocks in each portfolio are subdivided by their BE/ME ratio. 30 percent of the stocks with the highest and lowest $\mathrm{BE} / \mathrm{ME}$ ratios are allocated to the high and low portfolio, respectively, while the remaining 40 percent are sorted into the medium portfolio. The portfolio composition is maintained for a holding period of 12 months. This procedure results in an annual average of 1,672 general equities in each size portfolio from June 201 to June 2014. Monthly average total returns are calculated for each portfolio and are equal-weighted in euro currency. SMB is the return on a portfolio mimicking the risk factor related to size and is calculated as the average of monthly total returns on the three small-stock portfolios minus the average of monthly total returns on the three big-stock portfolios. HML is the return on a portfolio mimicking the risk factor related to $\mathrm{BE} / \mathrm{ME}$ and is calculated as the average of monthly total returns on the two high-BE/ME portfolios minus the average of monthly total returns on the two low-BE/ME portfolios. The market factor is calculated as the equal-weighted average excess return of all stocks in the final sample and denominated in euro currency. The risk-free rate is the equal-weighted average of all 16 one-month interbank rates.

\begin{tabular}{|c|c|c|c|c|c|c|}
\hline & Mean & SD & Median & Q1 & $\begin{array}{l}\text { Q3 } \\
\end{array}$ & Skew \\
\hline Returns & 0.0059 & 0.0986 & 0.0028 & -0.0352 & 0.0445 & 1.6034 \\
\hline Beta & 0.7101 & 0.5081 & 0.5928 & 0.3435 & 0.9613 & 1.6171 \\
\hline Size $10^{4}$ & 1,523 & 1,005 & 1,331 & 1,145 & 1,781 & 3.7454 \\
\hline $\mathrm{BE} / \mathrm{ME}$ & 1.1372 & 0.6344 & 1.0277 & 0.8114 & 1.3089 & 2.0545 \\
\hline Mom & 0.2067 & 0.3914 & 0.0913 & -0.0842 & 0.2772 & 4.2931 \\
\hline Liq & 0.7183 & 6.6753 & 0.0061 & 0.0011 & 0.0385 & 52.6166 \\
\hline CoSkew & -0.0619 & 0.2755 & -0.0793 & -0.2516 & 0.0988 & -0.0137 \\
\hline IV I & 0.0750 & 0.0861 & 0.0541 & 0.0395 & 0.0753 & 2.0288 \\
\hline IV II & 0.0665 & 0.079 & 0.0423 & 0.0277 & 0.0661 & 7.1785 \\
\hline
\end{tabular}

Table I shows the descriptive statistics for the sample of insurance equities. The cross-section regressions are starting in June 2001 to allow for the forecasting of idiosyncratic volatility and the estimation of beta and co-skewness, and therefore the statistics are for the period June 2001 to June 2014. The average monthly excess return amounts to 0.59 percent. The average beta is 0.71 and insurance equities therefore participate under-proportional in market movements, while the average size is over than that of the general equity market $(1,523 €-1,143 €$ million $)$. The average BE/ME of 1.13 also highlights the value stock characteristics of European insurance equities. The average momentum amounts to 20.67 percent and the Amihud liquidity measure to 0.7183 . On average, European insurance equities contribute negatively to the skewness of the market portfolio, as indicated by a co-skewness of 20.06. As size and $\mathrm{BE} / \mathrm{ME}$ are significantly skewed, they are used in natural logarithms for the subsequent cross-sectional analysis. Realized idiosyncratic volatility (IV I) averages 7.5 percent, while the EGARCH forecasted idiosyncratic volatility (IV II) is as high as 6.65 percent.

When estimating the expected idiosyncratic volatility; measure, 37.0 percent of all forecasts are yielded by an EGARCH $(1, q)$ model, 31.0 percent by an EGARCH $(2, q)$ model, and the remaining 32.0 percent by an $\operatorname{EGARCH}(3, q)$ model. Regarding the q-periods of return shocks, 58.0 percent are forecasted using an EGARCH $(\mathrm{p}, 1)$ model, 28.2 percent an EGARCH $(\mathrm{p}, 2)$ model, and 13.8 percent using an EGARCH $(p, 3)$ model. As the EGARCH $(2,1)$ is the best-fitting model for most of the forecasts (20.2 percent), this highlights the importance of having more than one lag in forecasting idiosyncratic volatility.

The time-series averages of cross-sectional correlations between excess returns and the independent variables. Excess returns are measured in month $t$ and $t-1$ while beta, size, $\mathrm{BE} / \mathrm{ME}$, momentum, liquidity, co-skewness and realized idiosyncratic volatility (IV I) are based on month $t-1$. Expected idiosyncratic volatility (IV II) is forecasted for month $t$ using observations up to month $t$-1. Simple correlations indicate that returns are positively related to beta, $\mathrm{BE} / \mathrm{ME}$ and momentum and negatively related to size, liquidity and co-skewness. Both measures of idiosyncratic volatility are negatively related to excess returns, indicating that higher realized or forecasted idiosyncratic volatility might result in lower expected returns. Realized and forecasted idiosyncratic volatility are positively related to beta, BE/ME, liquidity and co-skewness and negatively related to size and momentum. The correlation between both idiosyncratic volatility measures is as high as 0.470 .

\section{Cross Sectional Evidences}

This section analyses the pricing of both realized and expected idiosyncratic volatility in the cross-section of insurance equity returns as described in Section 3. Month-by-month, individual excess equity returns are regressed on lagged firm characteristics such as beta, size, $\mathrm{BE} / \mathrm{ME}$, momentum, co-skewness and liquidity, along with lagged realized idiosyncratic volatility or forecasted expected idiosyncratic volatility as described in equation (1). Beta, $\mathrm{BE} / \mathrm{ME}$, momentum and liquidity are expected positively related to expected returns, while the opposite holds for size and co-skewness. The analysis is conducted in three steps. First, the lagged firm characteristics; beta, size and BE/ME, momentum, liquidity, and finally co-skewness; are added in the regressions, (model 1). Second, both measures of idiosyncratic volatility are included in the regressions separately and their significance is assessed (models 2 and 3 ). 
Third, the pricing of idiosyncratic risk is analyzed in the framework of Pettengill as in Spiegel and et al. [13], as conditional on the performance of the general and real estate equity market as described in equation (5).

\section{TABLE II: UNCONDITIONAL CROSS-SECTION REGRESSIONS}

\begin{tabular}{|c|c|c|c|}
\hline Model & 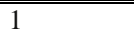 & 2 & 3 \\
\hline Int & $\begin{array}{l}0.011 \\
(2.210)^{* *}\end{array}$ & $\begin{array}{l}0.011 \\
(2.210)^{* * *}\end{array}$ & $\begin{array}{l}0.012 \\
(2.583)^{*}\end{array}$ \\
\hline Beta & $\begin{array}{l}0.004 \\
(0.987)\end{array}$ & $\begin{array}{l}0.004 \\
(0.987)\end{array}$ & $\begin{array}{l}0.004 \\
(0.872)\end{array}$ \\
\hline Size & $\begin{array}{l}-0.002 \\
(-1.854)^{*}\end{array}$ & $\begin{array}{l}-0.002 \\
(-1.854)^{*}\end{array}$ & $\begin{array}{l}-0.002 \\
(-2.114) * *\end{array}$ \\
\hline $\mathrm{BE} / \mathrm{ME}$ & $\begin{array}{l}0.006 \\
(4.058) * * *\end{array}$ & $\begin{array}{l}0.006 \\
(4.058)^{* * * *}\end{array}$ & $\begin{array}{l}0.005 \\
(3.506) * * *\end{array}$ \\
\hline Mom & $\begin{array}{l}0.014 \\
(1.511)\end{array}$ & $\begin{array}{l}0.014 \\
(1.511)\end{array}$ & $\begin{array}{l}0.014 \\
(1.553)\end{array}$ \\
\hline $\mathrm{Liq}$ & $\begin{array}{l}0.003 \\
(1.150)\end{array}$ & $\begin{array}{l}0.003 \\
(1.150)\end{array}$ & $\begin{array}{l}0.003 \\
(1.052)\end{array}$ \\
\hline CoSkew & $\begin{array}{l}-0.002 \\
(-0.513)\end{array}$ & $\begin{array}{l}-0.002 \\
(-0.513)\end{array}$ & $\begin{array}{l}0.004 \\
(0.991)\end{array}$ \\
\hline IV I & & $\begin{array}{l}-0.031 \\
(-1.109)\end{array}$ & \\
\hline IV II & & & $\begin{array}{l}-0.014 \\
(-0.664)\end{array}$ \\
\hline Adj $R^{2}$ & 0.132 & 0.138 & 0.141 \\
\hline
\end{tabular}

Significant at: $* 10, * * 5$ and $* * * 1$ percent levels

Table III depicts the unconditional cross-section regression results. As model 1 shows, the unconditional relationship between beta and expected returns is flat. Size seems to be negatively priced in the cross-section of insurance equity returns, while $\mathrm{BE} / \mathrm{ME}$ is positively related to expected returns. Momentum, liquidity and co-skewness are not related to average expected returns in an unconditional setting.

In models 2 and 3, both idiosyncratic volatility measures are added separately to the aforementioned models. While the inclusion increases the average adjusted $\mathrm{R}^{2}$ substantially, neither realized nor idiosyncratic volatility seems to be unconditionally priced in the cross-section of insurance equity returns. This results support the conception of the modern portfolio theory and the CAPM in that idiosyncratic risk is diversifiable and that an investor should not be rewarded for being exposed to avoidable risk.

\begin{tabular}{|c|c|c|c|}
\hline \multicolumn{4}{|c|}{ Panel I - general equity market states } \\
\hline \multicolumn{4}{|c|}{ Up-markets } \\
\hline Model & 1 & 2 & 3 \\
\hline Int & $\begin{array}{l}0.002 \\
(2.430)^{* *}\end{array}$ & $\begin{array}{l}0.004 \\
(2.650)^{* * *}\end{array}$ & $\begin{array}{l}0.008 \\
(2.443)^{*}\end{array}$ \\
\hline Beta & $\begin{array}{l}0.004 \\
(0.945)\end{array}$ & $\begin{array}{l}0.003 \\
(0.964)\end{array}$ & $\begin{array}{l}0.008 \\
(0.875)\end{array}$ \\
\hline Size & $\begin{array}{l}-0.006 \\
(-1.844)^{*}\end{array}$ & $\begin{array}{l}-0.001 \\
(-1.874)^{*}\end{array}$ & $\begin{array}{l}-0.006 \\
(-2.174) * *\end{array}$ \\
\hline $\mathrm{BE} / \mathrm{ME}$ & $\begin{array}{l}0.016 \\
(4.044) * * *\end{array}$ & $\begin{array}{l}0.016 \\
(4.076) * * *\end{array}$ & $\begin{array}{l}0.015 \\
(3.585)^{* * *}\end{array}$ \\
\hline Mom & $\begin{array}{l}0.004 \\
(1.533)\end{array}$ & $\begin{array}{l}0.006 \\
(1.532)\end{array}$ & $\begin{array}{l}0.006 \\
(1.532)\end{array}$ \\
\hline Liq & $\begin{array}{l}0.003 \\
(1.143)\end{array}$ & $\begin{array}{l}0.003 \\
(1.143)\end{array}$ & $\begin{array}{l}0.003 \\
(1.043)\end{array}$ \\
\hline CoSkew & $\begin{array}{l}-0.004 \\
(-0.534)\end{array}$ & $\begin{array}{l}-0.004 \\
(-0.534)\end{array}$ & $\begin{array}{l}0.005 \\
(0.975)\end{array}$ \\
\hline IV I & & $\begin{array}{l}-0.005 \\
(-1.142)\end{array}$ & \\
\hline IV II & & & $\begin{array}{l}-0.003 \\
(-0.654)\end{array}$ \\
\hline Adj $R^{2}$ & 0.132 & 0.138 & 0.141 \\
\hline
\end{tabular}

Down-markets

\begin{tabular}{|c|c|c|c|}
\hline Model & 1 & 2 & 3 \\
\hline Int & $\begin{array}{l}0.013 \\
(2.250)^{* * *}\end{array}$ & $\begin{array}{l}0.013 \\
(2.250)^{* *}\end{array}$ & $\begin{array}{l}0.014 \\
(2.566)^{*}\end{array}$ \\
\hline Beta & $\begin{array}{l}0.005 \\
(0.987)\end{array}$ & $\begin{array}{l}0.005 \\
(0.987)\end{array}$ & $\begin{array}{l}0.005 \\
(0.872)\end{array}$ \\
\hline Size & $\begin{array}{l}-0.002 \\
(-1.854)^{*}\end{array}$ & $\begin{array}{l}-0.002 \\
(-1.854)^{*}\end{array}$ & $\begin{array}{l}-0.002 \\
(-2.114)^{* *}\end{array}$ \\
\hline $\mathrm{BE} / \mathrm{ME}$ & $\begin{array}{l}0.006 \\
(4.058) * * *\end{array}$ & $\begin{array}{l}0.006 \\
(4.058) * * *\end{array}$ & $\begin{array}{l}0.005 \\
(3.506) * * *\end{array}$ \\
\hline Mom & $\begin{array}{l}0.015 \\
(1.561)\end{array}$ & $\begin{array}{l}0.016 \\
(1.561)\end{array}$ & $\begin{array}{l}0.016 \\
(1.593)\end{array}$ \\
\hline Liq & $\begin{array}{l}0.008 \\
(1.160)\end{array}$ & $\begin{array}{l}0.008 \\
(1.160)\end{array}$ & $\begin{array}{l}0.008 \\
(1.062)\end{array}$ \\
\hline CoSkew & $\begin{array}{l}-0.004 \\
(-0.573)\end{array}$ & $\begin{array}{l}-0.004 \\
(-0.573)\end{array}$ & $\begin{array}{l}0.006 \\
(0.951)\end{array}$ \\
\hline IV I & & $\begin{array}{l}-0.035 \\
(-1.159)\end{array}$ & \\
\hline IV II & & & $\begin{array}{l}-0.015 \\
(-0.674)\end{array}$ \\
\hline $\operatorname{Adj} R^{2}$ & 0.132 & 0.138 & 0.141 \\
\hline
\end{tabular}

Panel II - Insurance equity market states

\begin{tabular}{|c|c|c|c|}
\hline \multicolumn{4}{|c|}{ Up-markets } \\
\hline Model & 1 & 2 & 3 \\
\hline Int & $\begin{array}{l}0.013 \\
(2.240)^{* *}\end{array}$ & $\begin{array}{l}0.013 \\
(2.240)^{* *}\end{array}$ & $\begin{array}{l}0.015 \\
(2.573)^{*}\end{array}$ \\
\hline Beta & $\begin{array}{l}0.006 \\
(0.987)\end{array}$ & $\begin{array}{l}0.006 \\
(0.987)\end{array}$ & $\begin{array}{l}0.006 \\
(0.872)\end{array}$ \\
\hline Size & $\begin{array}{l}-0.002 \\
(-1.854)^{*}\end{array}$ & $\begin{array}{l}-0.002 \\
(-1.854)^{*}\end{array}$ & $\begin{array}{l}-0.002 \\
(-2.114)^{* * *}\end{array}$ \\
\hline $\mathrm{BE} / \mathrm{ME}$ & $\begin{array}{l}0.006 \\
(4.058)^{* * *}\end{array}$ & $\begin{array}{l}0.006 \\
(4.058)^{* * * *}\end{array}$ & $\begin{array}{l}0.005 \\
(3.506)^{* * *}\end{array}$ \\
\hline Mom & $\begin{array}{l}0.013 \\
(1.561)\end{array}$ & $\begin{array}{l}0.013 \\
(1.561)\end{array}$ & $\begin{array}{l}0.013 \\
(1.563)\end{array}$ \\
\hline Liq & $\begin{array}{l}0.007 \\
(1.170)\end{array}$ & $\begin{array}{l}0.007 \\
(1.160)\end{array}$ & $\begin{array}{l}0.007 \\
(1.062)\end{array}$ \\
\hline CoSkew & $\begin{array}{l}-0.003 \\
(-0.543)\end{array}$ & $\begin{array}{l}-0.003 \\
(-0.543)\end{array}$ & $\begin{array}{l}0.008 \\
(0.981)\end{array}$ \\
\hline IV I & & $\begin{array}{l}-0.034 \\
(-1.139)\end{array}$ & \\
\hline IV II & & & $\begin{array}{l}-0.016 \\
(-0.644)\end{array}$ \\
\hline $\operatorname{Adj} R^{2}$ & 0.132 & 0.138 & 0.141 \\
\hline \multicolumn{4}{|c|}{ Down-markets } \\
\hline Model & 1 & 2 & 3 \\
\hline Int & $\begin{array}{l}0.014 \\
(2.240)^{* *}\end{array}$ & $\begin{array}{l}0.015 \\
(2.250)^{* *}\end{array}$ & $\begin{array}{l}0.017 \\
(2.573)^{*}\end{array}$ \\
\hline Beta & $\begin{array}{l}0.005 \\
(0.947)\end{array}$ & $\begin{array}{l}0.005 \\
(0.937)\end{array}$ & $\begin{array}{l}0.006 \\
(0.842)\end{array}$ \\
\hline Size & $\begin{array}{l}-0.003 \\
(-1.874)^{*}\end{array}$ & $\begin{array}{l}-0.003 \\
(-1.874)^{*}\end{array}$ & $\begin{array}{l}-0.003 \\
(-2.164)^{* *}\end{array}$ \\
\hline $\mathrm{BE} / \mathrm{ME}$ & $\begin{array}{l}0.004 \\
(4.048)^{* * * *}\end{array}$ & $\begin{array}{l}0.004 \\
(4.088)^{* * * *}\end{array}$ & $\begin{array}{l}0.007 \\
(3.546)^{* * *}\end{array}$ \\
\hline Mom & $\begin{array}{l}0.015 \\
(1.551)\end{array}$ & $\begin{array}{l}0.013 \\
(1.541)\end{array}$ & $\begin{array}{l}0.013 \\
(1.563)\end{array}$ \\
\hline Liq & $\begin{array}{l}0.007 \\
(1.140)\end{array}$ & $\begin{array}{l}0.006 \\
(1.140)\end{array}$ & $\begin{array}{l}0.006 \\
(1.082)\end{array}$ \\
\hline CoSkew & $\begin{array}{l}-0.006 \\
(-0.543)\end{array}$ & $\begin{array}{l}-0.006 \\
(-0.543)\end{array}$ & $\begin{array}{l}0.008 \\
(0.941)\end{array}$ \\
\hline IV I & & $\begin{array}{l}-0.034 \\
(-1.169)\end{array}$ & \\
\hline IV II & & & $\begin{array}{l}-0.013 \\
(-0.664)\end{array}$ \\
\hline $\operatorname{Adj} R^{2}$ & 0.132 & 0.138 & 0.141 \\
\hline
\end{tabular}

Significant at: $* 10, * * 5$ and $* * * 1$ percent levels

However, the results are quite different when examined in the conditional framework, which is presented in Table IV.

When conditioned on the general equity market (Panel I), beta is positively related to expected returns in up-markets and negatively in down-markets. Size seems to be negatively related to returns in both market states, although with a 
greater coefficient and significance in down-markets. There is strong evidence of a positive relationship between BE/ME and expected returns in up-markets and a negative relationship in down-markets. Momentum is unrelated to returns in up-markets, while being positively priced in down-markets. Moreover, there seems to be some indication that illiquidity is negatively related to returns in up-markets while being positively related to expected returns in down-markets. Co-skewness is negatively related to returns in up-markets and positively related in down-markets. The results concerning the two idiosyncratic volatility measures are striking.

In the conditional setting, both measures are positively related to expected returns in up-markets and negatively in down-markets. As stocks with higher idiosyncratic volatility are ceteris paribus more risky than their counterparts, one would expect investors to receive a premium for holding such stocks when the stock market goes up. Vice versa, when the stock market goes down, the more risky stocks should yield lower returns than their counterparts. The results support this conception. Similar to the unconditional regressions, the average adjusted $\mathrm{R}^{2}$ increases substantially.

When conditioned on the insurance equity market (Panel II), the results are qualitatively identical. Both idiosyncratic volatility measures are positively related to returns in up- and negatively related in down-markets. One noticeable difference is the - although insignificant - positive coefficients on size when conditioned on insurance up-markets, which were negative in Panel I. There is also an indication of $\mathrm{BE} / \mathrm{ME}$ being positively priced in down-markets and momentum being negatively priced in up-markets.

A series of robustness checks is conducted to ensure the validity of the results.

- Currency effects

To account for potential distortions due to currency movements, all returns are denominated in the respective local currency and both idiosyncratic volatility measures are recomputed. The results indicate no qualitatively differing results. While size is now priced significantly negatively in all general equity up-market models, BE/ME loses some of its explanatory power in down-markets. Concerning insurance equity market states, BE/ME is now positively related to returns in almost all down-market models. Momentum and illiquidity cease to be significantly priced in up-markets and co-skewness in down-markets. All measures of idiosyncratic volatility remain highly significant in up- and down-market phases. Therefore, potential currency effects do not influence the results.

- Weighting effects

To account for potential effects due to the weighting procedure when calculating the Fama-French factors and therefore both measures of idiosyncratic volatility, all returns are value- instead of equal-weighted and the idiosyncratic volatility measures are recomputed. In the unconditional setting, the results do not change significantly except for momentum, which is now positively related to returns in most of the examined models. When conditioned on the general equity market, co-skewness ceases to be significantly related to returns in up-market states and BE/ME in down-market states. When conditioned on the real estate market, size evokes a positive risk premium in up-markets, while momentum, illiquidity and co-skewness lose their explanatory power in up-market states. Most interestingly are the results concerning both idiosyncratic volatility measures. When general equity market states are examined, both are with the exception of three significances at the 10 percent level in models 1,5 and 10 - unrelated to returns in up-markets. While still being related to returns in real estate up-markets, the significance levels are much lower than in the original model. Also, the evidence on the negative pricing of expected idiosyncratic volatility in general equity down-markets is weakened. While the overall conclusions can still be validated, the results emphasize the importance of the return weighting procedure.

- Country effects

The approach of pooling all countries in one sample assumes that investors evaluate the risk factors on a pan-European level and not for each country individually. If some countries have higher levels of risk (e.g. higher BE/ME, higher idiosyncratic volatility) than other countries, the results might actually be defined by country effects rather than the examined risk factor. To eliminate country effects, each month, all explanatory variables are regressed on country dummies:

$$
\begin{gathered}
9 x_{n, t}={ }_{t}+{ }_{j=1}^{J 1}{ }_{J, t} C_{n, j}+{ }_{n, t} \\
n=1,2, \ldots, N_{t} ; \quad j=1,2, \ldots, J \quad 1 ; \quad t=1,2, \ldots, T
\end{gathered}
$$

- Proxies of expected idiosyncratic volatility

The proposed measure of expected idiosyncratic volatility uses a minimum of 30 and a maximum of 60 observations to estimate rolling EGARCH forecasts. As the quality of the EGARCH estimations and forecasts critically depends on a sufficient amount of observations, two alternative proxies are examined. The first uses an expanding rather than rolling window as in $\mathrm{Fu}$ [5], requiring a minimum of 30 observations and adding new observations as the regressions are rolled forward. The second uses all available observations when estimating the conditional volatilities. While this induces a look-ahead bias, it might result in more stable estimates as the number of observations used to estimate the model is significantly increased. The results show that the findings do not depend on the utilized measure of idiosyncratic volatility. Both measures remain insignificant in the unconditional model while being positively related to returns in up-markets and negatively related in down-market phases.

\section{CONCLUSION}

The purpose of this study is to examine the role of idiosyncratic risk in the pricing of European insurance equities. The CAPM of Sharpe [40] predicts that in equilibrium investors should hold the market portfolio in which idiosyncratic risk irrelevant in the pricing of risky assets. However, there are several external factors, which impede investors from holding sufficiently diversified portfolios. Subsequent extensions of the CAPM such as those of Merton [1] and Malkiel and Xu [3] postulate a positive relationship between idiosyncratic risk and the cross-section of expected returns. 
By analyzing a broad set of 203 insurance equities from 12 European capital markets over the 2001-2014 period, this study adds to the understanding of the barely investigated pricing of European insurance equities. The unconditional cross-sectional analysis reveals that both measures of idiosyncratic risk fail to achieve significance at reasonable levels, supporting the conception of the MPT and CAPM that idiosyncratic risk is irrelevant in the pricing of risky assets. However, once conditioned on the general equity market or real estate equity market, a strong positive relationship between idiosyncratic risk and expected returns emerges in up-markets, while the opposite relationship exists in down-markets. Moreover, the average $R^{2}$ increases substantially after idiosyncratic risk is considered in the pricing models. The relationship endures the inclusion of beta, size, BE/ME, momentum, liquidity and co-skewness. It is also robust to:

- return currency;

- return weighting;

- country effects; and

- the measure of expected idiosyncratic volatility.

The findings show that both investors and insurance companies need a broader understanding of how to manage idiosyncratic risk. Following the suggestions of Becchetti and et al. [41], and Bekaert and et al. [42], companies should manage their earnings variability, capital structure, liquidity risk, leverage and performance in order to impact on idiosyncratic risk levels. Similarly, investors need to consider the aforementioned factors as well the utilized firm-characteristics of this study as an indication on the inherent level of idiosyncratic risk. Companies and investors should also consider idiosyncratic risk when estimating required returns or the cost of capital on European insurance equities and to set investment specific hurdle rates. The results might also help investors to improve their risk assessment and perform time-varying investment strategies, as high idiosyncratic risk equities outperform their counterparts in up-markets and vice versa. From an academic point of view, the results show that ignoring the conditional relationship between idiosyncratic risk and returns might result in the false realization that idiosyncratic risk does not matter in the pricing of risky assets. Further research needs to be conducted to fully understand the components of idiosyncratic risk and how these impact on the pricing of insurance equities. First, alternative-pricing models that include other known risk factors such as a liquidity or momentum factor could be used to derive the idiosyncratic risk measures. Second, several insurance-specific risk factors such as a insurance market beta, SMB, HML as well as the performance of the underlying direct property market might be priced risk factors for insurance equities but be considered idiosyncratic in the sense of the applied pricing model. Therefore, including these factors as insurance market specific risk factors might yield more inside on the pricing of idiosyncratic risk for European insurance equities.

\section{REFERENCES}

[1] R. C. Merton, "A simple model of capital market equilibrium with incomplete information," The Journal of Finance, vol. 42 no. 3, pp. 483-510, 1987.
[2] W. N. Goetzmann and A. Kumar, "Equity portfolio diversification," Review of Finance, vol. 12 no. 3, pp. 433-463, 2008.

[3] B. G. Malkiel and Y. Xu, "Idiosyncratic risk and security returns," unpublished manuscript, Department of Economics, Princeton University Citeseer, 2006.

[4] E. F. Fama and J. D. MacBeth, "Risk, return, and equilibrium: Empirical tests," Journal of Political Economy, vol. 81 no. 3, pp. 607-636, 1973.

[5] F. Fu, "Idiosyncratic risk and the cross-section of expected stock returns," Journal of Financial Economics, vol. 91, no. 1, pp. 24-37, 2009.

[6] M. W. Brandt, A. Brav, J. R. Graham, and A. Kumar, "The idiosyncratic volatility puzzle: time trend or speculative episodes?" Review of Financial Studies, vol. 23 no. 2, pp. 863-899, 2010.

[7] W. Huang, Q. Liu, S. G. Rhee, and L. Zhang, "Return reversals, idiosyncratic risk, and expected returns," Review of Financial Studies, vol. 23 , no. 1 , pp. 147-168, 2010

[8] E. F. Fama and K. R. French, "Common risk factors in the returns on stocks and bonds," Journal of Financial Economics, vol. 33, pp. 3-56, 1993.

[9] E. Eiling, "Industry-specific human capital, idiosyncratic risk and the cross-section of expected stock returns," Journal of Finance, vol. 68, issue 1, pp. 43-84, 2013.

[10] T. G. Bali and N. Cakici, "Idiosyncratic volatility and the cross section of expected returns," Journal of Financial and Quantitative Analysis, vol. 43, no. 1, pp. 29-58, 2008.

[11] X. Jiang and B. S. Lee, "The dynamic relation between returns and idiosyncratic volatility," Financial Management, vol. 35, no. 2, pp. 43-65, 2006.

[12] V. Panousi and D. Papanikolaou, Investment, Idiosyncratic Risk, and Ownership, vol. 67, issue 3, pp. 1113-1148, 2012.

[13] M. Spiegel and X. Wang, "Cross-sectional variation in stock returns: liquidity and idiosyncratic risk," unpublished manuscript, Yale School of Management, 2007.

[14] C. T. Chua, J. Goh, and Z. Zhang, "Expected volatility, unexpected volatility, and the cross-section of stock returns," Journal of Financial Research, vol. 33, no. 2, pp. 103-123, 2010.

[15] F. Fu, "On the robustness of the positive relation between expected idiosyncratic volatility and expected return," unpublished manuscript, Singapore Management University, 2010.

[16] R. Garcia, D. Mantilla-Garcia, and L. Martellini, "Idiosyncratic risk and the cross-section of stock returns," unpublished manuscript, EDHEC-Risk Institute, 2011.

[17] T. G. Bali, N. Cakici, X. S. Yan, and Z. Zhang, "Does idiosyncratic risk really matter?" The Journal of Finance, vol. 60, no. 2, pp. 905-929, 2005.

[18] Z. Chen and R. Petkova, "Does idiosyncratic volatility proxy for risk exposure?" The Review of Financial Studies, vol. 25, no. 9, pp. 2745-2787, 2012.

[19] S. X. Wei and C. Zhang, "Idiosyncratic risk does not matter: a re-examination of the relationship between average returns and average volatilities," Journal of Banking \& Finance, vol. 29, no. 3, pp. 603-621, 2005.

[20] R. D. Boehme, B. R. Danielsen, P. Kumar, and S. M. Sorescu, "Idiosyncratic risk and the cross-section of stock returns: Merton (1987) meets Miller (1977)," Journal of Financial Markets, vol. 12, no. 3, pp. 438-468, 2009.

[21] H. Guo andR. Savickas, "Idiosyncratic volatility, stock market volatility, and expected stock returns," Journal of Business and Economic Statistics, vol. 24, no. 1, pp. 43-56, 2006.

[22] J. D. Fink, K. E. Fink, and H. He, "Idiosyncratic volatility measures and expected return," unpublished manuscript, James Madison University, 2010.

[23] A. Ang, R. J. Hodrick, Y. Xing, and X. Zhang, 2006, "The cross-section of volatility and expected returns," The Journal of Finance, vol. 61, no. 1, pp. 259-299.

[24] M. E. Drew, N. Tony, and M. Veeraraghavan, "Is idiosyncratic volatility priced? Evidence from the Shanghai stock exchange," International Review of Financial Analysis, vol. 13, no. 3, pp. 349-366, 2004.

[25] M. E. Drew, M. Malin, T. Naughton, and M. Veeraraghavan, "Idiosyncratic volatility and security returns: evidence from Germany and United Kingdom," Studies in Economics and Finance, vol. 23, no. 2, pp. 80-93, 2006.

[26] H. Guo and R. Savickas, "Average idiosyncratic volatility in G7 countries," Review of Financial Studies, vol. 21, no. 3, p. 1259, 2008.

[27] T. Angelidis andN. Tessaromatis, "Does idiosyncratic risk matter? Evidence from European stock markets," Applied Financial Economics, vol. 18, no. 2, pp. 125-137, 2008. 
[28] P. Brockman, M. G. Schutte, and W. Yu, "Is idiosyncratic risk priced? The international evidence," unpublished manuscript, University of Missouri, 2009.

[29] A. Ang, R. J. Hodrick, Y. Xing, and X. Zhang, "High idiosyncratic volatility and low returns: international and further US evidence," Journal of Financial Economics, vol. 91, no. 1, pp. 1-23, 2009.

[30] J. L. M. Marcelo, M. M. M. Quiro's, and J. L. M. Quiro's, "Idiosyncratic risk really drives stock returns: Spanish evidence," unpublished manuscript, Department of Financial Economics, University of Extremadura, 2011.

[31] K. Storesletten, C. Telmer, A. Yaron, "Asset pricing with idiosyncratic risk and overlapping generations," Review of Economic Dynamics, Elsevier, 2007.

[32] X. Luo and C. Bhattacharya, "The debate over doing good: Corporate social performance, strategic marketing levers, and firm-idiosyncratic risk," Journal of Marketing, 2009.

[33] P. Choi and M. Weiss, "An empirical investigation of market structure, efficiency and performance in property-liability insurance," Journal of Risk and Insurance, vol. 72, pp. 635-673, 2005.

[34] Fama, E. F. and K. R. French, "The cross-section of expected stock returns," The Journal of Finance, vol. 47, no. 2, pp. 427-465, 1992.

[35] C. Kearney and V. Poti, "Have European stocks become more volatile? An empirical investigation of idiosyncratic and market risk in the Euro area," European Financial Management, vol. 14, no. 3, pp. 419-444, 2008.

[36] G. Bekaert, R. J. Hodrick, and X. Zhang, "Aggregate idiosyncratic volatility," unpublished manuscript, Graduate School of Business, Columbia University, 2010.

[37] H. Guo, H. Kassa, and M. F. Ferguson, "On the relation between EGARCH idiosyncratic volatility and expected stock returns," unpublished manuscript, Department of Finance and Real Estate, University of Cincinati, August 2011.

[38] D. Morelli, "European capital market integration: An empirical study based on a European asset pricing model," Journal of International
Financial Markets, Institutions and Money, vol. 20, no. 4, pp. 363-375, 2010.

[39] O. S. Ince and R. B. Porter, "Individual equity return data from Thomson Datastream: handle with care!" Journal of Financial Research, vol. 29, no. 4, pp. 463-479, 2006.

[40] W. F. Sharpe, "Capital asset prices: a theory of market equilibrium under conditions of risk," The Journal of Finance, vol. 19, no. 3, pp. 425-442, 1964.

[41] L. Becchetti, R. Ciciretti, and I. Hasan, "Corporate social responsibility, stakeholder risk, and idiosyncratic volatility," Journal of Corporate Finance, Elsevier, pp. 1- 27, 2015.

[42] G. Bekaert, R. J. Hodrick, and X. Zhang, "International stock return comovements," The Journal of Finance, vol. 64, no. 6, pp. 2591-2626, 2009.

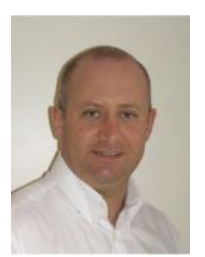

Hassen Rais was born on April 28, 1970 at Algiers, Algeria. French Citizen. He got a master in mathematics (ENSEEA), master in economics and doctorat of Management from Université of Toulouse, France. The fileds of his interest are: quantitative methods, Finance and risk management.

He has experience in insurance sector. Presently he is a professor of finance and risk management at Université of Toulouse, France. His publications is follow: "Analysis of financial risks management strategies: Towards modeling the risk management" in Management Studies. "Empirical determinants of business insurances in non-financial firms: Are they different from derivatives' determinants?" in Journal of Business and Economics. "Comparative analysis of the financial risks management determinants: An empirical approach" in Business Management Review. Dr. Rais is member of AIMS as reviewer and Editorial board member of Management Studies. 